in which he has violated the proprieties of the situntion and has expressed his opinion with reference to or in connection with a settlement then pending, the courts have avoided relenses on the ground of mutual mistake, where subsequent experience has shown that the physician was in fact wrong. I3nt it does not at all follow that in every case wherein there is a subsequent discovery of mutual mistake made by the de. fendant's physiciun as to the subsequent course of the plaintifi's injury, that a releuse executed nfter the mistake has been made is void. Into which class a particulur case under consideration should properly fall must depend on its peculiar circumstances. Where an attending physician in the course of trentment expresses a mistaken, but honest, opinion as to the period within which the injured person, suffering from a known injury, would recover, und where that expression of opinion, when made, had no comnertion whatever with a settlement, or with negotintions for a settlement, a release exernted in reliance on his statement, may in certain cuses properly be held valid.

\section{Society Proceedings}

\section{COMING MEETINGS}

Mawailan 'Teritorial M[ed. Assn.. Ilonolula Nov smber 20(i-28. Southern Surg. and Gyn. Assn. Nashrille. Dec. 13-15. Western Sitrg. and Gyn. Assn., Chlengo, Dec. 19-20.

\section{MINNESOTA STATE MEDICAL ASSOCIATION}

Allual Afeting, hold at Ifinneapolis, Oct. 6-7, 1910

The P'resident, Dr. W. A. Jones, Minneapolis, in the Chair

\section{Address of the President: The State Medical Association and} Its Relationship to the Problems of the Day

Dr. W. A. Jones, Minnenpolis: The first problem suggested for considerution is how to secure a live interest and discus. sion on the yearly program. The men in the country are either over-modest or inditlerent, and the burden of preparing papers falls on a few mell from the chicf eities in the state. The man in the country is often a man of idens, gleaned from hard-earned experience and worked out withont assistance, and the busiest man is the man who usually fiuds time for literary work outside of the hours devoted to prictice.

Another problem is suggested by the inability of medien nen, organized into nssociations or societies, to secure the ercation of a national department of health. This is an illustration of the need of further systematic effort to impress legislators and congressmen with the necessity of safeguarding the public heulth. The opposition to this movement is composed of a cosmopolitan crowd, who fear restraint or loss of their illegal means of livelihood by the manufacture and sale of frauduent remedies, nostrums or applinnces. It is further supplemented by narrow-minded people, who through ignorance or superstition exploit the new fads and cults incidental to the century. including opposition to vaccination, vivisection and other methods of advincing scientific information. The national and loeal League of Medical Freedom, supported by a few sensational newspapers, is striving to arouse public sentiment agninst medianl, sanitary and lygienic progress. In spite of this opposition, a crimpaign of education by medical men must go on relentlessly. Much good has alrendy been accomplished by the exposure of fraudulent remedies and fakers, who live on the misfortunes of the sick. The greatest difficulty is to get this information before the laymen. Physicians know of these frauds, but cannot always present proofs to their patients. The only remedy lies in the eduention of the masses to separate the good from the bad.

I strongly urge the employment of a journalist, who will acquaint himself with the fundamental needs of the people as advocated by physicians, and who will use his journalistic attainments and become a medical press agent. As physicians, we must learn to attend strictly to our own professional work and suspend personal abuse of fakers and newspapers, until we have the contidence of the people and the press. Jegislators should ennct laws for the protection of the sick ngainst cults, charlatans and nostrums. Indecisive fenr on the part of the law-maker is responsible for the present unenviable condition that so widely prevails.

All departments in the state which have to do with public health measures siould be asked to send representatives to confer with a lepi-lative committee composed of representa. tives from the state medical association, the bourd of health, the university alumi und the smitury conference. The members of the Minuesota State Medical Association should take more active interest in and familiarize themselves with the work of the state hospitnls and institutions. The medieal school of the state university deserves the support of all of Minnesota's medical men.

\section{Case of Metastatic Gonorrheal Conjunctivitis}

1). Winflam R. Murray, Minneapolis: This was a case of a simultaneous bilateral conjunetivitis occurring in a patient the subject of gonorrhea. There was no involvement of the intrnocular structures. The lids were considerably swollen, there was a moderate conjunctival discharge, the bulbar conjunctiva was edematous, and an arthritis of the wrist joint accompanied the conjunctivitis. The flrst attack of conjunctivitis lusted ten days and subsided and after an interval of several days was followed by a second attack of conjunetivitis, involving both eyes. which was also attended by an arthritis. There was no intruocular involvement during either attack of conjunctivitis. No gonococei could be found in the conjunctival discharge. A diagnosis of the metastatic origin of a gonorrheal conjunctivitis is based on the bilateral involve. ment of the eyes, moderate nmount of discharge, slight swelling of the lids, chemosis of the bulbar conjunctiva, comparative mild course of the disease, tendency to recur, absence of gonococei in the conjunctival discharge, and evidence of a systemic gonorrhea.

Dr. C. D. Conkey, Duluth: The ease reported by Dr. Murray must have been of a metastatic nature, for microscopic examinations of the eye secretions were frequently made all through the attack without discovery of gonococei. The method of infection is probably by the direct entrance of the gonococei into the blood-strenm from the urethral tract. I have under my care at present a case of gonorrheal iritis with an arthritis of the right knee in which I administerod three injections, two of $25,000,000$ and one of $50,000,000$ gonococei. The larger dose was followed by a decided reartion, the malaise lasting for severnl days, the joint affection being clecidedly bettered, but no effect was produced on the inflamed eye.

\section{The Heart in Diseases of the Thyroid}

Dr. J. S. Grufludas, St. l'uul: That a relationship existed between the thyroid and the heart lus long been known. The credit, however, for bringing the subject prominently before the profession belongs to Professor Rose, who, in 1877, read before the Germun Surgicul Congress a paper in which he established the influence of tracheal obstruction on the right heart.

Since " paper in 1899 by Professor Kraus it has been generally conceded that, aside from any respiratory obstruction, the thyroid may produce carliac chunges through certain toxic inlluences. Goiter-heart may be classified as: mechanical, or Rose's heart, and toxic, or the groiter-heart of Kraus.

The symptoms of the mechanienl variety are those of dilatation and insuflicieney of the right heart in addition to those of trachenl obstruction. This form of cardinc disease is not peculiar to goiter but may be produced by pressure by ally tumor.

The type of heart described by Kraus is produced by the nltered or increased secretion of the thyroid acting on the regulatory mechanism. This may oceur in any form of goiter. Symptoms consist in strong and rapid leart action, with at times other evidences of hyperthyroidism. In many cases there is enlargement of the left ventricle, which can be seen with the fluorscope to be due to an incrensed diastolic diston- 
tion. Kraus tries to draw a distinct line between these cases and Basedow:s disease. Kocher includes in the sume cluss all eases presenting symptoms of thyroid intoxication. Cardiac symptoms are very common in goiter patient.s. Momnier found 25 per cent. showing distinct heart symptoms. Koclser calls attention to the fact that during or after the administration of iodin in ally form for goiter, symptoms of thyroid intoxication may develop, due to lypersecretion of the gland stimulated by the jodin. In goiter heart the ordinary heart remedies are of but little value. Iodin should be used with great care if at all. Toxic cases may be trented with rest, diet, sodium phosplinte, etc.. but here as in mechnical eases operation should not be too long deferred.

\section{Intraspinal Injections of Magnesium Sulphate in Tetanus}

Dr. Cart J. Horman, Mankato: 'T'wo cases of tetanus were treated by magnesium sulphate injection. One eame on nine or ten days after a crushing injury to the ring and middle fingers of the left hand, necessitnting amputation. The symptoms of tetanus developed about the tenth day and the patient was given two doses of magnesium sulphate into the spinal canal, dying four lowes ufter the last dose. Case 2 was an appendiceal abscess. The patient developed tetamus on the eleventh or twelfth day after the operation and jeceived in all twenty-five doses of magnesium sulphate into the spinal canal. He made a good recovery and is now well, performing farm labor.

(To be (antinucu)

\section{IDAHO STATE MEDICAL ASSOCIATION}

Etghtecnth Annual Mceting, Held at Boive, Oct. 6-7, 19to

The President, Dr. Jorn M. Taybon, Boise, in the Chair

Hon. J. T. Pence, Mayor of Boise, made an address of welcome, which was responded to by Dr. J. L. Stewart of Boise.

\section{Officers Elected}

The following officers were elected for the ensuing year: president, Dr. John W. Givens, Orofino; vice-president, Jr. Grorge O. A. Kellogg, Nampa; chaiman committee on urrangements, Dr. J. W. Gue, Caldwell; chairman committer on legislation, Dr. J. M. Taylor, Boise; clnirman committee on nominations, Dr. J. C. Woodward, liayette; ehairnan committee on public health, Dr. G. H. Coulthard, Idaho Falls; trustees for Northwest Medicine, Dr. R. I. Nourse, Boise (reelected); Dr. J. W. Givens, Orofino (reolectel), and Dr. W. 'T. Drysdale, New Plymouth; delegrate to Anerican Medical Association, Dr. A. A. Iliggs, Bojse; alteruate, Dr. C. L. Dutton, Meridian.

Bcise was selected as the place of the next meeting.

\section{President's Address: Principles in Etiology and Treatment of Disease}

DR. JoIn M. TAYLOR, Boise, read his ammul address on the above sulject.

\section{DISCUSSION}

Dr. W. T. Williamson, Portinnd: The profession has done much in developing the study of medical subjects among the laity. Public education along the lines of persomal hygiene and unhenlthful habits is of great inportance. physicians must rench the young through the tenchers in the sehools. A competent member of the profession should be in attendance at all gatherings of teachers and lose no opportunity of instilling these thoughts into their ninds.

Dr. Geonge E. Hyde, Rexburg: It is evident to all that we are getting away from the era of superstition; medicine, through education, is less a mystery.

\section{Spinal Anesthesia}

De. C. C. Snyoer, Salt Lake City: I have confined the use of spinal anesthesia to cases in which a general anesthetic was unsuitable. With the use of strychnin and atropin in connection with the spinal injections, there seemed to be less headache and nausea following. I prefer tropacocnin to other cocain preparations, but it does not act so well above the diaphragm as does the hydrochlorate of cocain. In my experience the chief contra-indication to spinal anesthesia is a possible idiosynerusy to the drug.

\section{DIsCUsSTON}

Dn. A. E. Rockey, Portland: In a series of 25 or 30 cases in which $I$ used cocain, I had 2 cases of anuria. Subsequently I. used tropacocain in about an equal number of cases, and found it to be safer, but it did not seem so active as an anesthetic.

\section{Surgery of the Large Intestines}

Dr. A. E. Rockex, Portland, read this paper.

\section{DISCUSSION}

Dr. E. K. Scotr, Boise: Very few cases of malignant disease of the lower bowel are seen early enough to justify resection. I have seen many such operations, and know of but one case in which satisfactory results followed resection for malignant disease. In spite of the objectionable features of colotomy, I prefer to advise it in advaneed cases. In trentment of colitis, irrigations and local treatment through the rectum can be done more easily and with the same good results as Dr. Rockey reports from appendicostomy.

1)R. J. I. S'TEwart, Boise: I have done several resections for malignant disease of large bowel; I agree with Dr. Scott in believing that resection in these cases, unless the growth is low down, is not usunlly satisfnetory.

DR. J. M. 'TAYLon, Boise: Which incision does Dr. Rockey consider most advantagreous, and would ptosis of the abdominal organs complicate the operation?

DR. A. E. Rockey, Portland: The remarks of Dr. Scott refer more to the older methods of operating. By the newer methods, posterior incision, removal of coccyx, etc., I have found it easy to get room for removal of the tumor and to bring the bowel down. Prolapse of the sigmoid does not complicate the technic; if anything, it makes it easier. I have been using the transverse incision for some time in all appen. dectomies, and only through accident discovered its advantages in exposing the large bowel.

\section{Important Facts Concerning Myopia in Children}

]). Edward E. Maxey, Boise, read this paper.

$$
\text { Drscussion }
$$

DR. R. L. Nourse, Boise: Myopia is one of the penalties of civilization. Aborigines are not myopic. Students and those who apply their eyes closely for near work are apt to become myopic. Unless astigmatic, low degrees of myopia do not need glasses for confort, as is often the case in low degrees of hyperopia; hence they are often undetected until fairly well advanced.

Dr. W. 'T. Whidismson, Portland: There are a considerable number of nervous conditions caused by errors of refraction, especially in school children. For various reasons, school inspection is of vital importance to the child, especially inspection into the condition of the eyes, and, it is needless to say, these examinations should be made by competent men and repeated at frequent intervals.

DR. E. VAN NOTE, Boise: In the examination of ehildren's eyes we should emphasize the tendency myopia has of progressing, as very few parents understand its serionsness.

Dr. J. W. Givens, Orofino: In almost all forms of insanity very little help is to be had by correcting defects of vision. However, the relation of errors of refraction to lieadaches should be constuntly kept in mind in treating mental con. ditions.

Dr. E. E. MAXEY, Boise: Children of myopic parents are predisposed to myopia. Such children, after they reach the school age, should be examined once or twice a year. Low degrees of myopia, especially if astignatic, should be fully corrected and glasses changed as often as necessary. All examinations and reexaminations should be made under a reliable mydriatic, preferably atropin. If the myopin is progressing in spite of proper glasses, the child should be 